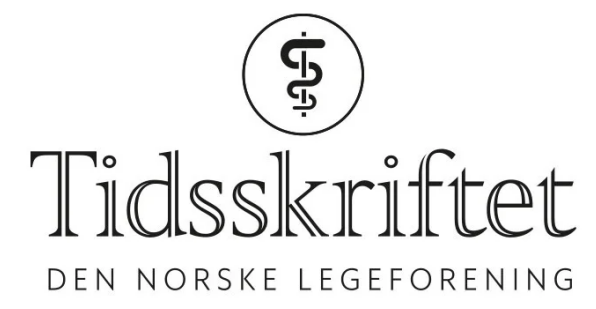

\title{
Fysisk belastning stimulerer både benvekst og immunsystem
}

FRA ANDRE TIDSSKRIFTER

HAAKON B. BENESTAD

Universitetet i Oslo

Celler som omslutter arterioler til benmargen i mus sanser bevegelse, svinner hen ved inaktivitet og aldring og forårsaker da knokkeltap og nedsatt infeksjonsmotstand.

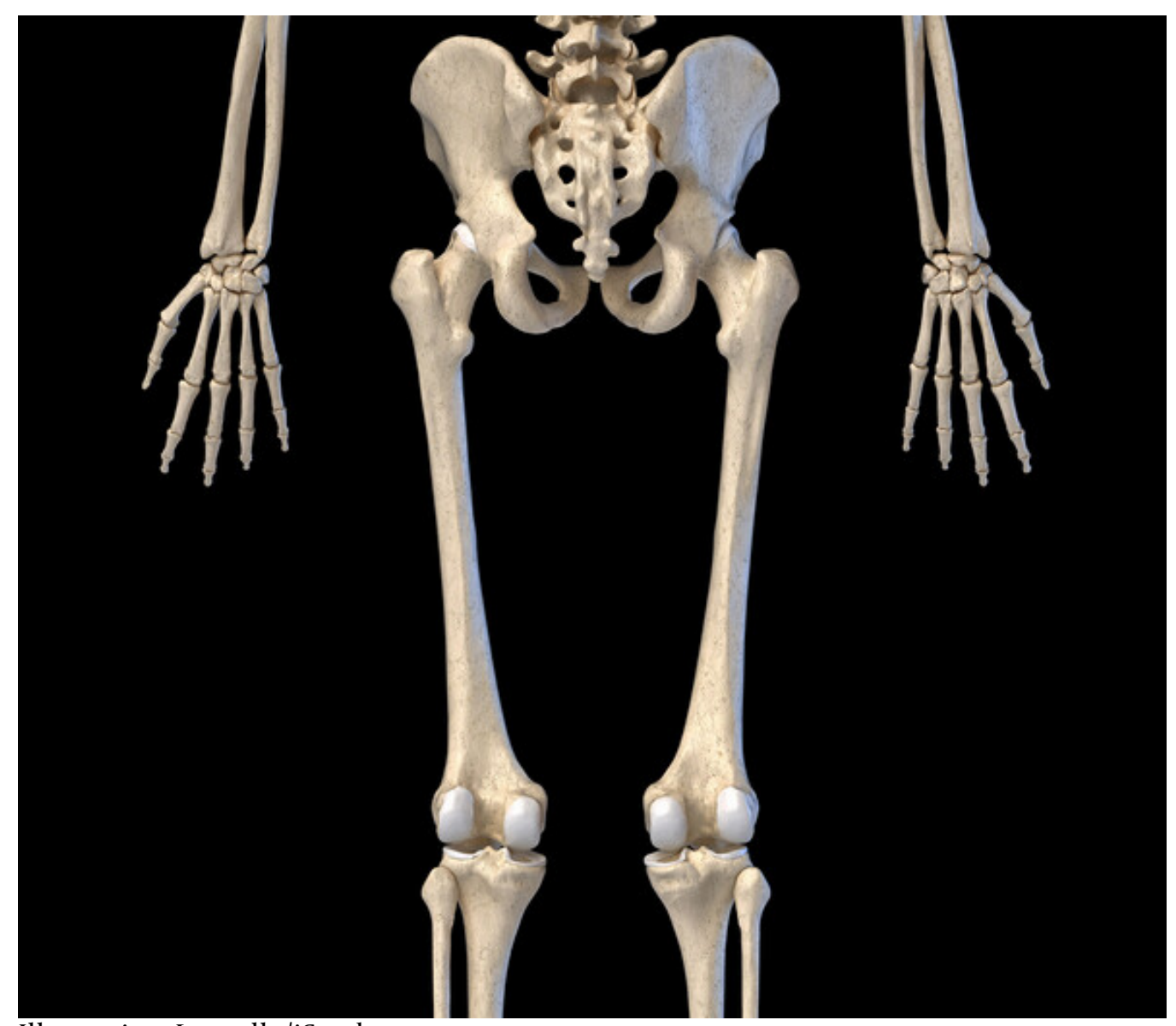

Illustrasjon: Leonello/iStock 
Diafysenes røde benmarg får blodforsyning bl.a. fra arterier i periost via arterioler gjennom den kompakte knokkelen. Noen mesenkymale benmargsceller har reseptorer for fettvevshormonet leptin, og noen av dem omslutter arteriolene og produserer den osteogene vekstfaktoren osteolektin.

En ny studie med genetisk modifiserte mus tok sikte på å påvise lokalisasjon og funksjon til leptin- og osteolektinpositive celler (1). Etter merking med en fluorescerende «merkelapp» viste væskestrømscytometri og konfokalmikroskopi at slike celler fantes rundt benmargsarteriolene. Muterte mus med utslått gen for en stamcellevekstfaktor i de leptinog osteolektinpositive cellene hadde færre lymfocyttprogenitorceller omkring arteriolene. Slike mus fikk redusert lymfocyttdannelse og infeksjonsforsvar mot bakterien Listeria monocytogenes.

Opprettholdelse av populasjonen av leptin- og osteolektinpositive celler var avhengig av mekanisk stimulering av knoklene, som når musene fikk løpe i tredemølle.

Knokkelavlastning ved suspensjon av musenes bakpart førte til at populasjonen ble redusert; det samme gjaldt for aldring. Løping førte også til celledeling og differensiering av de leptin- og osteolektinpositive cellene til osteoblaster som ga økt knokkelvekst (med unntak for kraniet).

Andre mekanoreseptorer, som arterienes baroreseptorer, har sanseceller med såkalte piezokanaler, som slipper inn kalsiumioner og har signaleffekter når de strekkes eller deformeres. Muterte mus uten en slik reseptor, PIEZO1, hadde svinn av både de leptin- og osteolektinpositive cellene og av lymfocyttprogenitorcellene.

- Dette er en meget elegant studie, som kobler fysisk belastning på knokler med en type stamceller i beinmargen, sier Kåre-Olav Stensløkken, som er professor ved Institutt for medisinske basalfag, Universitetet i Oslo.

- Vi har alle hørt at aktivitet styrker beinbygningen: jo hardere belastning jo bedre bein. Nå viser denne forskningsgruppen at det også er en sammenheng med stamceller som er viktige for immunsystemet, og at disse to mekanismene har sitt utspring fra samme celletype. Selv om disse forsøkene er gjort i mus, kan dette være en mekanisme som også er til stede hos mennesker, sier Stensløkken.

\section{LITTERATUR}

1. Shen B, Tasdogan A, Ubellacker JM et al. A mechanosensitive peri-arteriolar niche for osteogenesis and lymphopoiesis. Nature 2021; 591: 438-44. [PubMed][CrossRef]

Publisert: 4. august 2021. Tidsskr Nor Legeforen. DOI:10.4045/tidsskr.21.0430

(C) Tidsskrift for Den norske legeforening 2023. Lastet ned fra tidsskriftet.no 26. april 2023. 